\title{
An Eco-Friendly Solution for the Efficient Elimination of Pentoxifylline from Water: An Operational Performance Investigation
}

\author{
LUCIAN GAVRILA ${ }^{1}$, ANDREI-IONUT SIMION ${ }^{*}$, CRISTINA-GABRIELA GRIGORAS ${ }^{\text {1*, }}$ \\ LIDIA FAVIER ${ }^{2}$ \\ ${ }^{1}$ University Vasile Alecsandri of Bacau, Faculty of Engineering, Department of Chemical and Food Engineering, \\ 157 Calea Marasesti, 600115, Bacau, Romania \\ ${ }^{2}$ Univ Rennes, Ecole Nationale Supérieure de Chimie de Rennes, CNRS, ISCR - UMR6226, F-35000 Rennes, France
}

\begin{abstract}
In recent years, more and more pollutants (including pharmaceuticals, personal care products, pesticides, herbicides, hormones, chemicals) are detected in the aquatic environment. Even if they are encountered in very low concentrations, the toxicological data reveal that they represent a major risk both for the water living organisms and for human beings. Moreover, an important resistance to the classical methods applied at wastewater treatment plants characterizes them. Aeration, coagulation, flocculation, sedimentation, filtration, adsorption, oxidation, activated sludge treatments are often either insufficient or completely ineffective. To overcome these drawbacks, many researches were dedicated to the development of new effective techniques for the removal of these water pollutants. Advanced oxidation methods are widely reported as being of the most efficient ones. In this article, we investigate the utility of the photocatalysis as a sustainable alternative for the enhanced elimination of an emergent water micropollutant. We evaluate here the impact of several parameters (catalyst type and concentration, contaminant concentration, radiant flux intensity) on the process efficiency. The targeted compound involved in the experiments was the pentoxifylline (a drug used in the treatment of diseases such as diabetic neuropathy, osteoradionecrosis or hepatic fibrogenesis). The registered pollutant removal rate under the selected reaction conditions (photocatalyst type: ZnO; photocatalyst concentration: $0.5 \mathrm{~g} / \mathrm{L}$; incident light flux: $9.52 \mathrm{~mW} / \mathrm{cm}^{2}$; natural $\mathrm{pH}$ ) reached values near to $100 \%$ providing new insights on the viability and the efficiency of the evaluated methodology.
\end{abstract}

Keywords: emergent water pollutant, photocatalysis, titanium oxide, zinc oxide

\section{Introduction}

Water micropollutants are known as contaminants found in small concentrations (trace levels of $\mathrm{ng} / \mathrm{L}$ to $\mu \mathrm{g} / \mathrm{L}$ ) in the aquatic environment [1]. They include various types of natural or synthetic substances such as drugs (antidiabetic medicines, anaesthetics, analgesics, anti-inflammatories, antihypertensives, antivirals, fungicides, antibiotics, diuretics, anxiolytics, anticonvulsants, antidepressants, antihistamines, lipid-regulators) [2-4], personal care products (fragrances, disinfectants, UV filters, repellents) [5, 6], hormones (estrogens, testosterone, progesterone, mestranol) [7-9], chemicals (plasticizers, surfactants, dyes) used in different industrial areas (food, textile, paint, polymers) [10, 11], pesticides (insecticides, herbicides, fungicides) [12, 13] etc.

Their significant toxicity, high persistency, reduced biodegradability and important bioaccumulative ability $[14,15]$ cause many difficulties in the efforts of removing them from the water matrices. Conventional physical, chemical or biological procedures as aeration, coagulation, flocculation, sedimentation, filtration, adsorption, oxidation, activated sludge treatments are often either insufficient or completely ineffective [16-19].

*email:asimion@ub.ro,cristina.grigoras@ub.ro 
Over the last years, numerous approaches focused on the development of efficient and environmental friendly alternatives for the classical wastewater treatment techniques. The advanced oxidation processes (AOPs) are listed as conducting to very good results. One of the most popular AOPs is the photocatalysis [20] and many researches consider it as green and sustainable alternative reporting good outcomes for its application in the elimination of organic water contaminants. Indeed, several studies report on the successful photocatalytic degradation of pollutants including dyes, pesticides as well as phenolic compounds or antibiotics [21-26]. The concept is based on the generation of highly reactive oxygen species (hydroxyl radical, superoxide anion radical, hydroperoxyl radical, alkoxyl radical), with the main feature consisting in their ability to mineralize unselectively the organic pollutants to carbon dioxide, water and inorganic ions or acids [27]. Hence, this process was successfully applied for the destruction of various dangerous organic substances from wastewaters [2830]. It involves the pollutants transfer to the surface of a photocatalyst (titanium dioxide, zinc oxide, tungsten trioxide, strontium peroxide, zirconium dioxide, iron (III) oxide, cerium (IV) oxide etc.) where they are adsorbed and, under the action of photons, activated and decomposed [31]. A desorption of the reaction products and their removal from the photocatalyst surface complete the process [32].

The photocatalytic reaction starts when the photocatalysts absorb photons with equal or higher energy than that of their band gap (which is for example of $3.2 \mathrm{eV}$ for $\mathrm{TiO}_{2}$ anatase form and of $3.5 \mathrm{eV}$ for $\mathrm{ZnO}$ ) leading to molecular excitation and charge separation. The generated mobile electrons $\left(\mathrm{e}^{-}\right)$ and holes $\left(\mathrm{h}^{+}\right)$pairs can take part at an undesirable process of recombination and dissipation of the absorbed energy as heat or they can migrate to the catalysts surface. In the latter case, if the photocatalysis occurs in aqueous solutions, the electrons reduce oxygen into superoxide radical anions. In the same time, the holes react with water and hydroxide ions forming hydroxyl radicals that are responsible for the organic pollutants mineralization [33,34]. Keeping in mind all these considerations, the objective of this work was to evaluate the possibility of application of this eco-friendly process for removal of an emergent water contaminant named pentoxifylline (PTX). The considered target molecule is a methylxanthine derivative presenting properties comparable to theobromine, caffeine and theophylline and mainly used for the treatment of circulatory and cerebrovascular disorders, diabetic neuropathy, osteoradionecrosis and hepatic fibrogenesis [35]. Highly stable and soluble in water, PTX is a refractory and persistent compound which cannot be easily eliminated by the traditional water treatment methods. The process feasibility was firstly investigated in the presence of commercial photocatalysts under UV-A irradiation and then, in order to evaluate its potential application on the elimination of PTX, a detailed analysis of the effect of few of the main process parameters (photocatalyst amount, pollutant concentration, irradiation period and light intensity) was performed. The use of such strategy gives a better understanding on the existing correlation between these factors and the performance of degradation kinetics of the target molecule.

\section{Materials and methods}

\subsection{Reagents}

The pentoxifylline (PTX) (Table 1) was of analytical purity and procured from SIGMA (France).

Table 1. Pentoxifylline properties

\begin{tabular}{cc}
\hline Structure & $\mathrm{C}_{13} \mathrm{H}_{18} \mathrm{~N}_{4} \mathrm{O}_{3}$ \\
\hline Formula & $6493-05-6$ \\
\hline CAS number & 3,7-dimethyl-1-(5-oxohexyl)-3,7-dihydro- $1 \mathrm{H}$-purine- \\
2,6-dione
\end{tabular}




\begin{tabular}{lc}
\hline Molecular weight, $\mathrm{g} / \mathrm{mol}$ & 278.31 \\
\hline Water solubility, $\mathrm{mg} / \mathrm{mL}$ & 43 \\
\hline
\end{tabular}

$\mathrm{ZnO}\left(98 \%\right.$, specific surface: $9 \mathrm{~m}^{2} / \mathrm{g}$, particle diameter: $\left.110 \mathrm{~nm}\right), \mathrm{TiO}_{2}$ Cristalactiv ${ }^{\circledR} \mathrm{PC} 500\left(\mathrm{TiO}_{2}\right.$ content: wt $85 \%$, specific surface: $350 \mathrm{~m}^{2} / \mathrm{g}$, particle diameter: $5-10 \mathrm{~nm}$ ) and $\mathrm{TiO}_{2}$ Kronos 7500 (specific surface: $250 \mathrm{~m}^{2} / \mathrm{g}$, particle diameter: $15 \mathrm{~nm}$ ) used as photocatalysts were purchased from Alfa Aesar® (Kandel, Germany), Crystal (France) and Kronos (Germany), respectively.

Acetonitrile was supplied by Fisher Scientific (United Kingdom).

Ultrapure water $\left(18.2 \mathrm{M} \Omega \cdot \mathrm{cm} ; 25^{\circ} \mathrm{C}\right.$; DOC $\left.<5 \mu \mathrm{g} \mathrm{C} / \mathrm{L} ; p \mathrm{H}=6.5\right)$ used for PTX solutions preparation and for chromatographic analysis was obtained with a Purelab option-Q apparatus from Elga Labwater (Veolia, High Wycombe, United Kingdom).

\subsection{Experimental setup}

All the experiments on PTX removal were carried out at room temperature on a batch photoreactor system consisting in a cylindrical borosilicate glass reactor vessel of $1.5 \mathrm{~L}$ protected from sunlight and an UV-A lamp (PL-L 24W, Philips, Poland) with the main wavelength at $365 \mathrm{~nm}$ and two secondary wavelengths at $400 \mathrm{~nm}$ and $440 \mathrm{~nm}$.

PTX aqueous solutions of different concentrations and various amounts of catalysts were added in the reactor and agitated for $30 \mathrm{~min}$. Once the adsorption equilibrium was achieved, the UV lamp preheated outside for $30 \mathrm{~min}$ was introduced in the middle of the reactor.

The collected samples were filtered on Chromafil@ Xtra H-PTFE $0.45 \mu \mathrm{m}$ syringe filters (Macherey-Nagel, Düren, Germany) prior to other analysis.

\subsection{Chromatographic analysis}

The residual concentration of PTX was established by high-performance liquid chromatography (HPLC) analysis. A Waters 600 system (Milford, MA, USA) equipped with a Waters 717 plus Autosampler (Milford, MA, USA) and a Waters ${ }^{\text {TM }} 996$ photodiode array detector (Milford, MA, USA) set at $280 \mathrm{~nm}$ was used. The separation was performed at room temperature on a Symmetry C18 column $(250 \mathrm{~mm} \times 4.6 \mathrm{~mm}, 5 \mu \mathrm{m})$ from Waters (Ireland). The mobile phase was composed of water (solvent A) and acetonitrile (solvent B) and delivered in isocratic mode (70 \% A, $30 \% \mathrm{~B}$ ) with a flow of $1 \mathrm{~mL} / \mathrm{min}$. The sample injection volume was of $50 \mu \mathrm{L}$. The recorded retention time of PTX was of 3.5 minutes.

The quantitative measurements were realized based on an external PTX calibration curve. To this purpose, a PTX stock solution $(100 \mathrm{mg} / \mathrm{L}$ in acetonitrile) was prepared and then diluted to different concentrations $(5 \mathrm{mg} / \mathrm{L}, 10 \mathrm{mg} / \mathrm{L}, 20 \mathrm{mg} / \mathrm{L}, 40 \mathrm{mg} / \mathrm{L}, 80 \mathrm{mg} / \mathrm{L})$. The calculated correlation coefficient $\left(\mathrm{R}^{2}\right)$ between the peak area and the pollutant concentration was 0.9999 .

\section{Results and discussions}

\subsection{Catalyst type effect}

Three different catalysts, namely $\mathrm{TiO}_{2} \mathrm{PC} 500, \mathrm{TiO}_{2}$ Kronos 7500 , and $\mathrm{ZnO}$ were tested in this study to evaluate their efficiency in the elimination of the target molecule. Our photocatalytic experiments were conducted with an initial pollutant concentration of $10 \mathrm{mg} / \mathrm{L}$ and a catalyst amount of $0.5 \mathrm{~g} / \mathrm{L}$ in the presence of a maximal incident light flux $\left(9.52 \mathrm{~mW} / \mathrm{cm}^{2}\right)$.

As it can be seen in Figure 1, from the first minutes of photocatalysis, the degradation with $\mathrm{ZnO}$ is faster than that with $\mathrm{TiO}_{2}$ Kronos 7500 and with $\mathrm{TiO}_{2}$ PC500. In the case of $\mathrm{ZnO}$, the pollutant degradation reached a removal yield of $55 \%$ after only 10 min of irradiation while with $\mathrm{TiO}_{2}$ PC500 and $\mathrm{TiO}_{2}$ Kronos 7500 the observed photocatalytic efficiency was of 30 and $8 \%$ respectively. It must be pointed out that with the last mentioned catalyst the target molecule is not completely removed even after an irradiation time of $150 \mathrm{~min}$. The recorded data are consistent with those registered by Bansal and Verma [36] which reveal also only a low removal of PTX for the photocatalytic reaction with $\mathrm{TiO}_{2}$. 
Fenoll et al. [37] who studied the photo-oxidation of different insecticides in the presence of titanium and zinc oxides explain that the higher activity of $\mathrm{ZnO}$ can be attributed to its properties. In our case, $\mathrm{ZnO}$ is characterized by a reduced specific surface of $9 \mathrm{~m}^{2} / \mathrm{g}$ and by a more important particles diameter (110 $\mathrm{nm})$ compared to the other photocatalysts $\left(\mathrm{TiO}_{2}\right.$ Cristalactiv ${ }^{\circledR} \mathrm{PC} 500-350 \mathrm{~m}^{2} / \mathrm{g}, 5-10 \mathrm{~nm}$; $\mathrm{TiO}_{2} \mathrm{Kronos}$ $7500-250 \mathrm{~m}^{2} / \mathrm{g} ; 15 \mathrm{~nm}$ ). Moreover, according to Kitsiou et al. [38], zinc oxide possesses a higher electronic mobility, indicating lower charge recombination and therefore an enhanced reactivity.

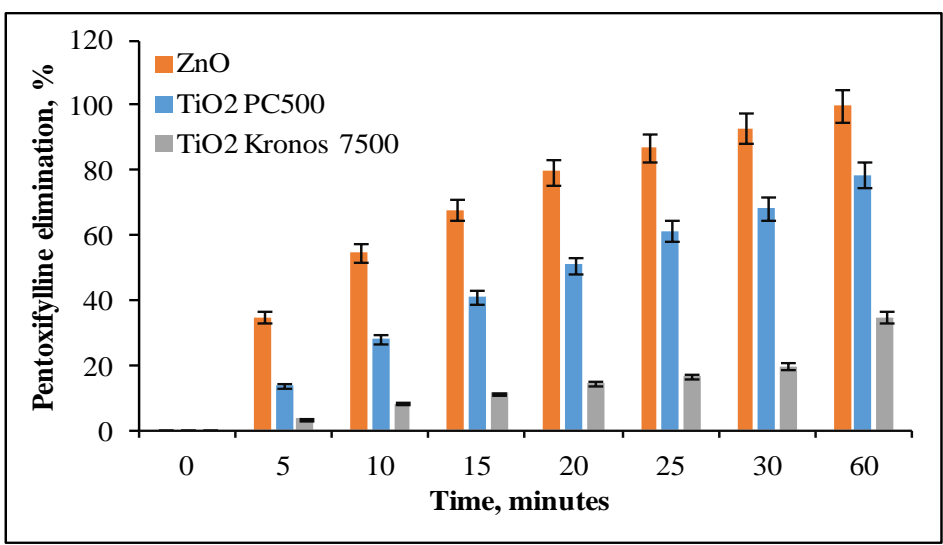

Figure 1. Influence of catalyst type on the elimination

of the target molecule initial pollutant concentration: $10 \mathrm{mg} / \mathrm{L}$;

incident light flux: $9.52 \mathrm{~mW} / \mathrm{cm}^{2}$; catalyst concentration: $0.5 \mathrm{~g} / \mathrm{L}$; natural $p \mathrm{H}$

\subsection{Adsorption, photolysis and photocatalysis}

After selecting the most appropriate catalyst, the influence of different conditions such as adsorption, photolysis and photocatalysis, on removing PTX from aqueous solutions was investigated. Several assays were carried out with an initial pollutant concentration of $10 \mathrm{mg} / \mathrm{L}, 0.5 \mathrm{~g} / \mathrm{L}$ of catalyst, and an incident light flux of $9.52 \mathrm{~mW} / \mathrm{cm}^{2}$. Figure 2 illustrates the fact that PTX is not eliminated in the dark and highlights that the adsorption equilibrium was reached in less than $60 \mathrm{~min}$. Similarly, a negligible pollutant removal was recorded during the photolytic reaction (data not shown). On the contrary, a significant reduction of PTX concentration was obtained when the system catalyst - UV-A was applied. Under these conditions, the target molecule was completely degraded in approximatively $60 \mathrm{~min}$. Our previous studies conducted on 2,4-diclorophenol [39] and on clofibric acid [40] revealed comparable findings in terms of the reduced efficiency of adsorption and photolysis and of the high utility of combining the effect of catalyst with that of the UV-A irradiation.

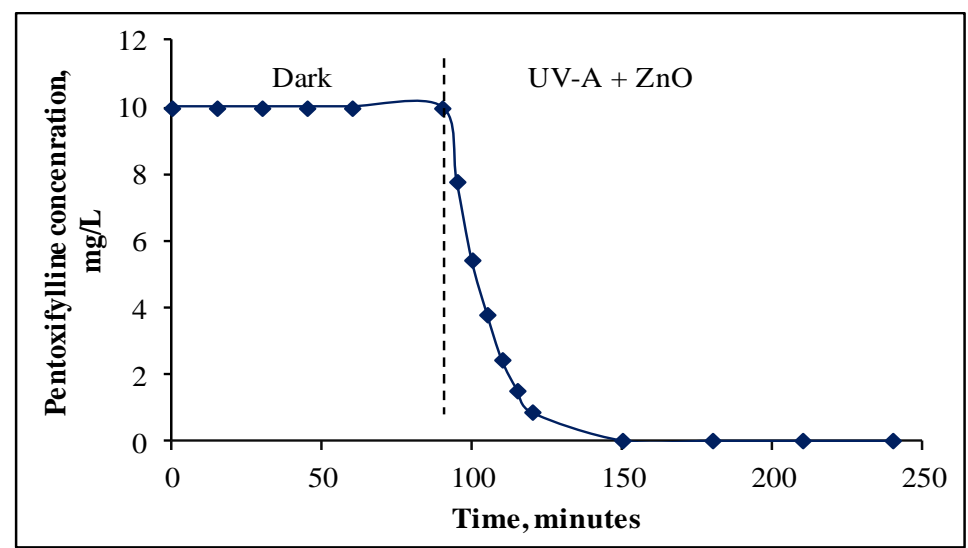

Figure 2. Influence of adsorption and photocatalysis on the

removal of the target pollutant initial pollutant concentration: $10 \mathrm{mg} / \mathrm{L}$; incident light flux: $9.52 \mathrm{~mW} / \mathrm{cm}^{2}$; catalyst concentration: $0.5 \mathrm{~g} / \mathrm{L}$; natural $p \mathrm{H}$ 


\subsection{Influence of photocatalyst concentration}

In a photocatalytic process the degradation kinetics are significantly affected by catalyst load. Indeed, at low photocatalyst concentrations, there is a risk that the active sites will not be sufficient to efficiently remove the pollutant from the treated solution. In addition, the process can be adversely affected also when catalyst loading is higher than an optimum dosage. Light scattering, screening effects, catalyst particle agglomeration, solution turbidity etc. can be observed in this case along with a drastic reduction of the degradation efficiency. Therefore, an optimal catalyst mass in the medium should be established in order to avoid the catalyst excess and to guarantee a maximum of active sites on its surface area available for reaction, which will increase the number of hydroxyl and of superoxide radicals, and will ensure a rapid elimination of the target contaminant $[28,33]$.

In the present study, we focused our attention on the investigation of the effect of this factor on the degradation of the target molecule. Thus, different tests were performed for a constant initial pollutant concentration of $10 \mathrm{mg} / \mathrm{L}$ while the catalyst dose in the aqueous solution was varied from $0.1 \mathrm{~g} / \mathrm{L}$ to $0.5 \mathrm{~g} / \mathrm{L}$. As depicted in Figure 3, more catalyst there is, faster the degradation occurs. $92.88 \%$ of the pollutant was degraded after only $30 \mathrm{~min}$ when $\mathrm{ZnO}$ was used at a concentration of $0.5 \mathrm{~g} / \mathrm{L}$. Amounts of $0.25 \mathrm{~g} / \mathrm{L}$ and of $0.1 \mathrm{~g} / \mathrm{L}$ led to $76.69 \%$ and $19.60 \%$ of PTX removal, respectively. According to these data, the concentration of $0.5 \mathrm{~g} / \mathrm{L}$ was considered as appropriate for the other experimental runs.

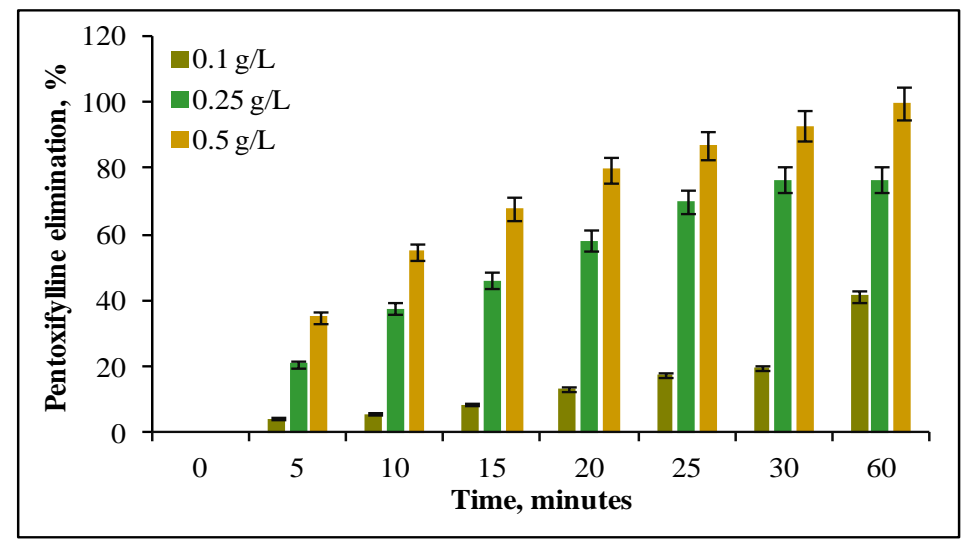

Figure 3. Influence of $\mathrm{ZnO}$ catalyst concentration on the pentoxifylline

Elimination initial pollutant concentration: $10 \mathrm{mg} / \mathrm{L}$; incident light flux: $9.52 \mathrm{~mW} / \mathrm{cm}^{2}$; natural $p \mathrm{H}$

Similarly, Rajeev et al. [41] demonstrated in their paper that, in the tested experimental conditions, the acetophene was efficiently removed by photocatalysis on $\mathrm{ZnO}$ only at the optimal catalyst concentration. For chlorpyrifos degradation Kanmoni et al. [42] used $\mathrm{ZnO}$ concentrations between 0.1 $\mathrm{g} / \mathrm{L}$ and $1 \mathrm{~g} / \mathrm{L}$ and showed that the best results were at a $\mathrm{ZnO}$ dosage of $0.75 \mathrm{~g} / \mathrm{L}$. Burbano et al. [43] quantified the elimination of dimethylamine salt of 2,4-dichlorophenoxyacetic acid by photodegradation and reported as appropriate a zinc oxide concentration of $0.35 \mathrm{~g} / \mathrm{L}$. Ceretta et al. [44] coupled the bacteria effect with that of a composite containing $\mathrm{ZnO}$ and polypyrrole and concluded that the adequate catalyst dosage for Direct Black azo dye degradation was of $2 \mathrm{~g} / \mathrm{L}$. On the contrary, when the concentration of the photocatalyst exceeds the optimal value, less light is allowed to pass through the photocatalyst surface, a light screening effect appears and the reaction rates descends $[33,45]$.

\subsection{Influence of initial pollutant concentration}

The initial pollutant concentration also affects the photocatalytic reaction efficiency. An augmentation of the target molecule concentration conducts to an increase of the absorbed substance on the catalyst active sites and consequently to a higher request of oxidizing species. Since the catalyst surface area remains the same for fixed photocatalytic conditions (catalyst load), at some point, the generation of hydroxyl radicals is unsatisfactory because there are only a few active sites available for 
the adsorption of hydroxyl ions. Additionally, the photons are no longer able to reach the catalyst surface $[40,46]$. Hence, all these aspects have a negative impact on the pollutant elimination.

In this regard, the photocatalytic degradation with different initial pollutant amounts was also examined in this work. A series of photocatalytic tests were conducted for different pollutant concentrations (ranging from $5 \mathrm{mg} / \mathrm{L}$ to $50 \mathrm{mg} / \mathrm{L}$ ) and for a catalyst load of $0.5 \mathrm{~g} / \mathrm{L}$. As expected, at lower initial concentration, the degradation rate was significantly increased (Figure 4). It was found that after 15 minutes of irradiation, the removal efficiency was $97.38 \%$ when the initial pollutant concentration was of $5 \mathrm{~g} / \mathrm{L}$ compared to $67.99 \%$ for a PTX load of $10 \mathrm{~g} / \mathrm{L}$ and to $28.04 \%$ for $50 \mathrm{~g} / \mathrm{L}$. After a reaction time of $30 \mathrm{~min}$, PTX elimination reached values of $100 \%, 92.88 \%$ and, respectively, $50.10 \%$.

Analogous influence of the initial emergent compounds concentration on the photocatalytic process efficiency was confirmed by other previous reports. In their work, Wang et al. [47] reveal that the ibuprofen photodegradation percentage decreases with the increase of its concentration in the aqueous solutions. Mahalakshmi et al. [48] who carried out experiments on removing carbofuran by photocatalysis with zinc oxide varying the contaminant concentration from $50 \mathrm{mg} / \mathrm{L}$ to $250 \mathrm{mg} / \mathrm{L}$ reported a similar behavior. In their work, Choina et al. [49] highlighted as well that the substrate concentration is one of the key factors affecting the water decontamination. They reported that the initial amount of tetracycline and ibuprofen existing in the solutions submitted to photocatalysis over $\mathrm{ZnO}$ nanoparticles contributes significantly to the process efficiency.

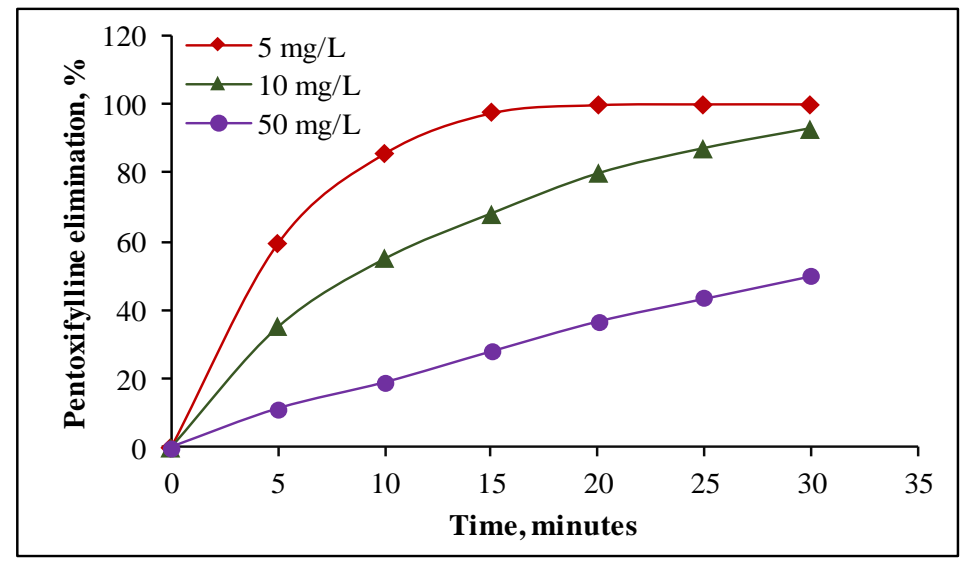

Figure 4. Influence of initial pollutant concentration on its eliminationZnO catalyst concentration: $0.5 \mathrm{~g} / \mathrm{L}$; incident light flux: $9.52 \mathrm{~mW} / \mathrm{cm}^{2}$; natural $p \mathrm{H}$

\subsection{Influence of light intensity}

The photodegradation of a PTX solution of $5 \mathrm{mg} / \mathrm{L}$ at a catalyst concentration of $0.5 \mathrm{~g} / \mathrm{L}$ was also carried out at three different values of light intensity in order to evaluate the effect of this process parameter on the compound degradation. The data obtained for each of investigated conditions were fitted as pseudo first order kinetics and the rate constants were determined as negative slope of linear regression of $\ln \left(C / C_{0}\right)$ over reaction time. For calculation purpose, $C$ was the pollutant concentration at a time $t$ and $C_{0}$ was its initial concentration.

As shown in Figure 5, at the maximal incident light flux $\left(9.52 \mathrm{~mW} / \mathrm{cm}^{2}\right)$ used in our experiments, the total degradation of PTX takes place in the first 20 minutes. 


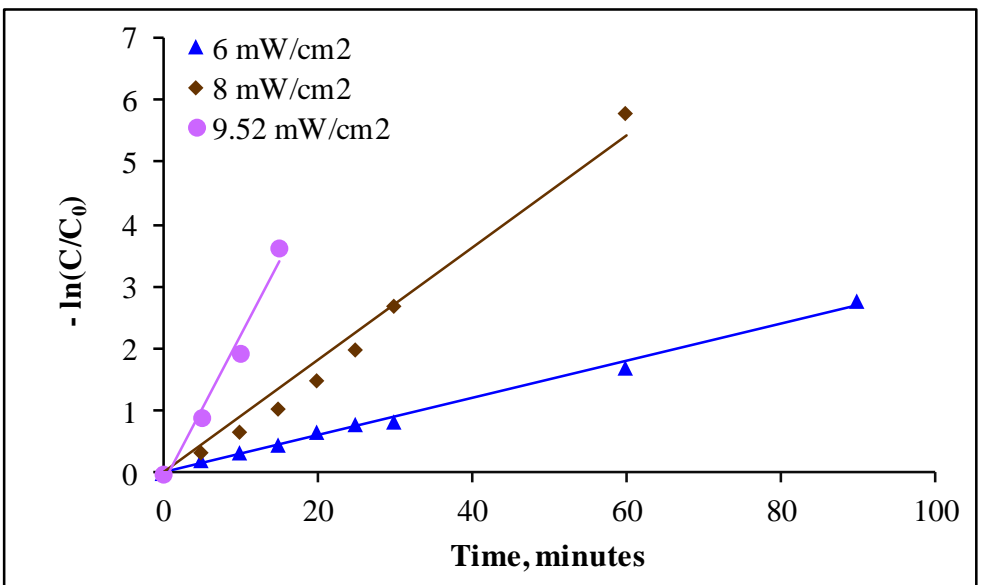

Figure 5. Influence of incident light flux on the photocatalytic degradation of the target pollutant catalyst concentration: $0.5 \mathrm{~g} / \mathrm{L}$; initial pollutant concentration: $5 \mathrm{mg} / \mathrm{L}$; natural $p \mathrm{H}$

On the contrary, when the light intensity decreases at $8 \mathrm{~mW} / \mathrm{cm}^{2}$ and at $6 \mathrm{~mW} / \mathrm{cm}^{2}$ the required time to reach the same pollutant elimination yield is three times and respectively six times more important. Thus, our results clearly demonstrates the beneficial effect of the incident light intensity on the elimination of the considered pollutant.

It is known that if the photocatalytic process is conducted under a certain light intensity an amelioration of the reaction rate can be remarked [50]. Such behavior can be explained by the fact that when the light intensity increases there is a higher probability that the number of active species (electron-holes pairs) formed increases correspondingly conducting to an augmentation of the photodegradation rate. The calculated values corresponding to kinetic rate constants obtained as a function of incident light flux used in our study as well as the obtained correlation coefficients are presented in Table 2. It can be observed that the degradation rate constants notably increase with the applied incident light intensity.

Table 2. Pseudo first order rate constants obtained for the degradation of the target molecule at different light intensities

\begin{tabular}{|c|c|c|}
\hline $\begin{array}{c}\text { Incident light flux, } \\
\mathrm{mW} / \mathrm{cm}^{2}\end{array}$ & Kinetic constant, min $^{-1}$ & $\begin{array}{c}\text { Correlation coefficient } \\
\left(\mathbf{R}^{2}\right)\end{array}$ \\
\hline 6 & 0.0299 & 0.9945 \\
\hline 8 & 0.0902 & 0.9778 \\
\hline 9.52 & 0.2244 & 0.9699 \\
\hline
\end{tabular}

Similar results about the existing correlation between the light intensity and the elimination rate were also reported by several studies carried out on different organic water pollutants. Nishio et al. [51] specify that the decolorization rate of Orange II solutions linearly increased with the increase of UV light intensity from $0 \mathrm{~W} / \mathrm{m}$ to $19.8 \mathrm{~W} / \mathrm{m}$. Other works showed that rhodamine B degradation rate constant increased with augmentation of light intensity from $10 \mathrm{~mW} / \mathrm{cm}^{2}$ to $60 \mathrm{~mW} / \mathrm{cm}^{2}$ [52]. Moreover, in their work, Elsellami et al. [53] demonstrated that the phenylalanine is faster degraded when the radiant flux varied from $0 \mathrm{~mW} / \mathrm{cm}^{2}$ to $10 \mathrm{~mW} / \mathrm{cm}^{2}$. These results are consistent with our data confirming the positive role of incident light flux on the photocatalytic process.

\section{Conclusions}

The registered data reveal that the photocatalysis can be successfully employed to remove refractory contaminants from aqueous solutions. 
Among the three catalysts tested $\left(\mathrm{TiO}_{2} \mathrm{PC} 500, \mathrm{TiO}_{2}\right.$ Kronos 7500 and $\left.\mathrm{ZnO}\right)$, zinc oxide had the utmost photocatalytic performance in terms of the elimination of pentoxifylline (the target compound). The experiments indicated that photolysis and adsorption mechanisms had a negligible influence on the removal efficiency, both UV-A and catalyst being necessary for the molecule degradation.

The photocatalytic process was considerably affected by the initial catalyst dosage and by the starting pollutant concentration. A major importance had also the value of the used radiant light flux, the best results being recorded at its maximum value $\left(9.52 \mathrm{~mW} / \mathrm{cm}^{2}\right)$. The assays carried out established that a pseudo-first-order kinetic model can describe the degradation of the studied micropollutant.

Our findings demonstrated that the photocatalytic process using UV-A and $\mathrm{ZnO}$ photocatalyst could be a potential technique for the elimination of emergent water contaminants.

\section{References}

1. LUO, Y., GUO, W., NGO, H.H., NGHIEM, L.D., HAI, F.I., ZHANG, J., LIANG, S., WANG, X.C., A Review on the Occurrence of Micropollutants in the Aquatic Environment and Their Fate and Removal During Wastewater Treatment, Sci. Total Environ., 473-474, 2014, 619-641.

2. ZHOU, S., DI PAOLO, C., WU, X., SHAO, Y., SEILER, T.-B., HOLLERT, H., Optimization of Screening-Level Risk Assessment and Priority Selection of Emerging Pollutants - The Case of Pharmaceuticals in European Surface Waters, Environ. Int., 128, 2019, 1-10.

3. CRISTEA, I.N., SOBETKI, A., CONSTANTIN, L.A., CONSTANTIN, M.A., NITOI, I., Ag-TiO 2 Assisted Photocatalytic Degradation of Cytostatic Drug Cyclophosphamide under UV-VIS Light, Rev. Chim., 71(4), 2020, 347-355.

4. WARNER, W., LICHA, T., NÖDLER, K., Qualitative and Quantitative Use of Micropollutants as Source and Process Indicators. A Review, Sci. Total Environ., 686, 2019, 75-89.

5. RANA, D., SCHEIER, B., NARBAITZ, R.M., MATSUURA, T., TABE, S., JASIM, S.Y., KHULBE, K.C., Comparison of Cellulose Acetate (CA) Membrane and Novel CA Membranes Containing Surface Modifying Macromolecules to Remove Pharmaceutical and Personal Care Product Micropollutants from Drinking Water, J. Membr. Sci., 409-410, 2012, 346-354.

6. YANG, Y.-Y., TOOR, G.S., WILSON, P.C., WILLIAMS, C.F., Micropollutants in Groundwater from Septic Systems: Transformations, Transport Mechanisms, and Human Health Risk Assessment, Water Res., 123, 2017, 258-267.

7. KHANSARY, M.A., MELlAT, M., SAADAT, S.H., FASIHI-RAMANDI, M., KAMALI, M., TAHERI, R.A., An Enquiry on Appropriate Selection of Polymers for Preparation of Polymeric Nanosorbents and Nanofiltration/Ultrafiltration Membranes for Hormone Micropollutants Removal From Water Effluents, Chemosphere, 168, 2017, 91-99.

8. ZHANG, J., NGUYEN, M.N., LI, Y., YANG, C., SCHÄFER, A.I., Steroid Hormone Micropollutant Removal from Water with Activated Carbon Fiber-Ultrafiltration Composite Membranes, J. Hazard. Mater., 391, 2020, 122020.

9. PHILliPS, P.J., SCHUBERT, C., ARGUE, D., FISHER, I., FURLONG, E.T., FOREMAN, W., GRAY, J., CHALMERS, A., Concentrations of Hormones, Pharmaceuticals and Other Micropollutants in Groundwater Affected by Septic Systems in New England and New York, Sci. Total Environ., 512-513, 2015, 43-54.

10. KIM, Y., FARNAZO, D.M., Toxicity Characteristics of Sewage Treatment Effluents and Potential Contribution of Micropollutant Residuals, J. Ecol. Environ., 41(1), 2017, 39-48.

11. GLASER, C., SCHWIENTEK, M., ZARFL, C., Designing Field-Based Investigations of Organic Micropollutant Fate in Rivers, Environ. Sci. Pollut. Res., 26(28), 2019, 28633-28649.

12. KANAUJIYA, D.K., PAUL, T., SINHAROY, A., PAKSHIRAJAN, K., Biological Treatment Processes for the Removal of Organic Micropollutants from Wastewater: A Review, Curr. Pollut. Rep., 5(3), 2019, 112-128. 
13. MUNZ, N.A., BURDON, F.J., DE ZWART, D., JUNGHANS, M., MELO, L., REYES, M., SCHÖNENBERGER, U., SINGER, H.P., SPYCHER, B., HOLLENDER, J., STAMM, C., Pesticides Drive Risk of Micropollutants in Wastewater-Impacted Streams During Low Flow Conditions, Water Res., 110, 2017, 366-377.

14. TOSUN, J., SCHAUB, S., FLEIG, A., What Determines Regulatory Preferences? Insights from Micropollutants in Surface Waters, Environ. Sci. Pol., 106, 2020, 136-144.

15. TRAPIDO, M., EPOLD, I., BOLOBAJEV, J., DULOVA, N., Emerging Micropollutants in Water/Wastewater: Growing Demand on Removal Technologies, Environ. Sci. Pollut. Res., 21(21), 2014, 12217-12222.

16. BENNER, J., HELBLING, D.E., KOHLER, H.-P.E., WITTEBOL, J., KAISER, E., PRASSE, C., TERNES, T.A., ALBERS, C.N., AAMAND, J., HOREMANS, B., SPRINGAEL, D., WALRAVENS, E., BOON, N., Is Biological Treatment a Viable Alternative for Micropollutant Removal in Drinking Water Treatment Processes?, Water Res., 47(16), 2013, 5955-5976.

17. GRANDCLÉMENT, C., SEYSSIECQ, I., PIRAM, A., WONG-WAH-CHUNG, P., VANOT, G., TILIACOS, N., ROCHE, N., DOUMENQ, P., From the Conventional Biological Wastewater Treatment to Hybrid Processes, the Evaluation of Organic Micropollutant Removal: A Review, Water Res., 111, 2017, 297-317.

18. BARBOSA, M.O., MOREIRA, N.F.F., RIBEIRO, A.R., PEREIRA, M.F.R., SILVA, A.M.T., Occurrence and Removal of Organic Micropollutants: An Overview of the Watch List of EU Decision 2015/495, Water Res., 94, 2016, 257-279.

19. FENYVESI, É., BARKÁCS, K., GRUIZ, K., VARGA, E., KENYERES, I., ZÁRAY, G., SZENTE, L., Removal of Hazardous Micropollutants from Treated Wastewater Using Cyclodextrin Bead Polymer - A Pilot Demonstration Case, J. Hazard. Mater., 383, 2020, 121181.

20. CAVAlu, S., VICAS, S., COSTEA, T., FRITEA, L., COPOlOVICI, D., LASlO, V., Preparation, Physico-Chemical Characterization and Photocatalytic Properties of Se Doped $\mathrm{TiO}_{2}$ Nanoparticles, Rev. Chim., 71(1), 2020, 22-27.

21. COLEMAN, H.M., VIMONSES, V., LESLIE, G., AMAL, A., Removal of Contaminants of Concern in Water Using Advanced Oxidation Techniques, Water Sci. Technol., 55(12), 2007, 301-306. 22. KAUR, A., UMAR, A., KANSAL, S.K., Heterogeneous Photocatalytic Studies of Analgesic and Non-Steroidal Anti-Inflammatory Drugs, Appl. Catal., A, 510, 2016, 134-155.

23. HWANGBO, M., ClAYCOMB, E.C., LIU, Y., ALIVIO, T.E.G., BANERJEE, S., CHU, K.-H., Effectiveness of Zinc Oxide-Assisted Photocatalysis for Concerned Constituents in Reclaimed Wastewater: 1,4-Dioxane, Trihalomethanes, Antibiotics, Antibiotic Resistant Bacteria (ARB), and Antibiotic Resistance Genes (ARGs), Sci. Total Environ., 649, 2019, 1189-1197.

24. WEI, Z., LIU, J., SHANGGUAN, W., A Review on Photocatalysis in Antibiotic Wastewater: Pollutant Degradation and Hydrogen Production, Chin. J. Catal., 41(10), 2020, 1440-1450.

25. WETCHAKUN, K., WETCHAKUN, N., SAKULSERMSUK, S., An Overview of Solar/Visible Light-Driven Heterogeneous Photocatalysis for Water Purification: $\mathrm{TiO}_{2}-$ and ZnO-Based Photocatalysts Used in Suspension Photoreactors, J. Ind. Eng. Chem., 71,2019, 19-49.

26. IHOS, M., BOGATU, M., LAZAU, C., MANEA, F., PODE, R., Pharmaceutically Active Compounds Degradation Using Doped $\mathrm{TiO}_{2}$ Functionalized Zeolite Photocatalyst, Rev. Chim., 69(1), 2018, 34-37.

27. KANAKARAJU, D., GLASS, B.D., OELGEMÖLLER, M., Advanced Oxidation Process-Mediated Removal of Pharmaceuticals from Water: A Review, J. Environ. Manag., 219, 2018, 189-207.

28. WANG, J., ZHUAN, R., Degradation of Antibiotics by Advanced Oxidation Processes: An Overview, Sci. Total Environ., 701, 2020, 135023.

29. ANJALI, R., SHANTHAKUMAR, S., Insights on the Current Status of Occurrence and Removal of Antibiotics in Wastewater by Advanced Oxidation Processes, J. Environ. Manag., 246, 2019, 51-62. 30. BABU, D.S., SRIVASTAVA, V., NIDHEESH, P.V., KUMAR, M.S., Detoxification of Water and Wastewater by Advanced Oxidation Processes, Sci. Total Environ., 696, 2019, 133961. 
31. DOS SANTOS, A.B.K., CLARO, E.M.T., MONTAGNOLLI, R.N., CRUZ, J.M., LOPES, P.R.M., BIDOIA, E.D., Electrochemically Assisted Photocatalysis: Highly Efficient Treatment Using Thermal Titanium Oxides Doped and Non-Doped Electrodes for Water Disinfection, J. Environ. Manag., 204, 2017, 255-263.

32. RUEDA-MARQUEZ, J.J., LEVCHUK, I., FERNÁNDEZ IBAÑEZ, P., SILlANPÄÄ, M., A Critical Review on Application of Photocatalysis for Toxicity Reduction of Real Wastewaters, $J$. Clean. Prod., 258, 2020, 120694.

33. TEH, C.M., MOHAMED, A.R., Roles of Titanium Dioxide and Ion-Doped Titanium Dioxide on Photocatalytic Degradation of Organic Pollutants (Phenolic Compounds and Dyes) in Aqueous Solutions: A Review, J. Alloys Compd., 509(5), 2011, 1648-1660.

34. LEE, K.M., LAI, C.W., NGAI, K.S., JUAN, J.C., Recent Developments of Zinc Oxide Based Photocatalyst in Water Treatment Technology: A Review, Water Res., 88, 2016, 428-448.

35. LAHSINI, R., MONSER, L., Optimization and Validation of a New HPLC Method Using Monolithic Column for Simultaneous Determination of Pentoxifylline and Related Compounds, Pharm. Chem. J., 46(2), 2012, 127-131.

36. BANSAL, P., VERMA, A., Novel $\mathrm{Fe}_{-} \mathrm{TiO}_{2}$ Composite Driven Dual Effect for Reduction in Treatment Time of Pentoxifylline: Slurry to Immobilized Approach, Materials \& Design, 125, 2017, 135-145.

37. FENOLl, J., GARRIDO, I., HELlíN, P., VELA, N., FlORES, P., NAVARRO, S., Photooxidation of Three Spirocyclic Acid Derivative Insecticides in Aqueous Suspensions as Catalyzed by Titanium and Zinc Oxides, J. Photochem. Photobiol., A, 328, 2016, 189-197.

38. KITSIOU, V., FILIPPIDIS, N., MANTZAVINOS, D., POULIOS, I., Heterogeneous and Homogeneous Photocatalytic Degradation of the Insecticide Imidacloprid in Aqueous Solutions, Appl. Catal., B, 86(1), 2009, 27-35.

39. FAVIER, L., SIMION, A.I., MATEI, E., GRIGORAȘ, C.-G., KADMI, Y., BOUZAZA, A., Photocatalytic Oxidation of a Hazardous Phenolic Compound Over $\mathrm{TiO}_{2}$ in a Batch System, Environ. Eng. Manag. J., 15(5), 2016, 1059-1067.

40. VRINCEANU, N. HLIHOR, R.M., SIMION, A.I., RUSU, L., FEKETE-KERTESZ, I., BARKA, N., FAVIER, L., New Evidence of the Enhanced Elimination of a Persistent Drug Used as a Lipid Absorption Inhibitor by Advanced Oxidation With UV-A and Nanosized Catalysts, Catalysts, 9, 2019, https://doi:10.3390/catal9090761.

41. RAJEEV, B., YESIDHARAN, S., YESODHARAN, E.P., Sunlight Activated ZnO Mediated Photocatalytic Degradation of Acetophenone in Water, J. Appl. Chem., 2016, 55-70.

42. KANMONI, V.G.K., DANIEL, S., RAJ, G.A.G., Photocatalytic Degradation of Chlorpyrifos in Aqueous Suspensions Using Nanocristals of $\mathrm{ZnO}$ and $\mathrm{TiO}_{2}$, Reac. Kinet. Mech. Cat., 106, 2012, 325339.

43. BURBANO, J., CRUZ, I., COLINA-MARQUEZ, J., LOPEZ-VASQUEZ, A., MACHUCA, F., Evaluation of Zinc Oxide-Based Photocatalytic Degradation of a Commercial Pesticide, J. Adv. Oxid. Technol., 11(1), 2016, 49-55.

44. CERETTA, M.B., VIEIRA, Y., WOLSKI, E.A., FOLETTO, E.L., SILVESTRI, S., Biological Degradation Coupled to Photocatalysis by $\mathrm{ZnO} /$ Polypyrrole Composite for the Treatment of Real Textile Wastewater, J. Water Proc. Eng., 35, 2020, 101230.

45. CONSTANTIN, L.A., NITOI, I., CRISTEA, I., OANCEA, P., Kinetics of 5-Fluorouracil Degradation by Heterogeneous $\mathrm{TiO}_{2}$ Photocatalysis, Rev. Chim., 67(8), 2016, 1447-1450.

46. MIRZAEI, A., CHEN, Z., HAGHIGHAT, F., YERUSHALMI, L., Removal of Pharmaceuticals and Endocrine Disrupting Compounds from Water by Zinc Oxide-Based Photocatalytic Degradation: A Review, Sust. Cities Soc., 27, 2016, 407-418.

47. WANG, Z., SRIVASTAVA, V., AMBAT, I., SAFAEI, Z., SILlANPÄ̈̈, M., Degradation of Ibuprofen by UV-Led/Catalytic Advanced Oxidation Process, J. Water Proc. Eng., 31, 2019, 100808. 
48. MAHALAKSHMI, M., ARABINDOO, B., PALANICHAMY, M., MURUGESAN, V., Photocatalytic Degradation of Carbofuran Using Semiconductor Oxides, J. Hazard. Mater., 143(1), 2007, 240-245.

49. CHOINA, J., BAGABAS, A., FISCHER, C., FLECHSIG, G.U., KOSSLICK, H., ALSHAMMARI, A., SCHULZ, A., The Influence of the Textural Properties of ZnO Nanoparticles on Adsorption and Photocatalytic Remediation of Water from Pharmaceuticals, Catal. Today, 241, 2015, 47-54.

50. SHAFAEI, A., NIKAZAR, M., ARAMI, M., Photocatalytic Degradation of Terephthalic Acid Using Titania and Zinc Oxide Photocatalysts: Comparative Study, Desalination, 252(1), 2010, 8-16.

51. NISHIO, J., TOKUMURA, M., ZNAD, H.T., KAWASE, Y., Photocatalytic Decolorization of Azo-Dye with Zinc Oxide Powder in an External UV Light Irradiation Slurry Photoreactor, J. Hazard. Mater., 138(1), 2006, 106-115.

52. LI, Y., SUN, S., MA, M., OUYANG, Y., YAN, W., Kinetic Study and Model of the Photocatalytic Degradation of Rhodamine $\mathrm{B}(\mathrm{RhB})$ by a $\mathrm{TiO}_{2}$-Coated Activated Carbon Catalyst: Effects of Initial RhB Content, Light Intensity And $\mathrm{TiO}_{2}$ Content in che Catalyst, Chem. Eng. J., 142(2), 2008, 147-155. 53. ELSELlAMI, L., VOCANSON, F., DAPPOZZE, F., PUZENAT, E., PAÏSSE, O., HOUAS, A., GUILLARD, C., Kinetic of Adsorption and of Photocatalytic Degradation of Phenylalanine Effect of pH and Light Intensity, Appl. Catal., A, 380(1), 2010, 142-148.

$\overline{\text { Manuscript received: } 20.05 .2020}$ 